\title{
A GLANCE AT ON UTILIZATION OF FIBRE IN THICK BITUMINOUS MACADAM
}

\author{
Reyaz Hussain Akhoon \\ Civil Engineering Department \\ RIMT University Mandi Gobindghar, Punjab, India
}

\begin{abstract}
Utilizing filaments universally is very simply like that in the U.S., i.e., the utilization of cellulose or mineral strands in Gap and Open-reviewed blends are standard in numerous nations. Generally, filaments seem like increasingly powerful at upgrading the exhibition of minimal or lower-five star blends. Expansion of polyester fiber to the bituminous blends will expand the vitality and security of the blend. A wide kind of fiber sorts has been used in black-top combos, which incorporate cellulose, mineral, counterfeit polymer, and glass strands, just as a couple of less ordinary fiber sorts. The present examination is to investigate the format blend (DBM-I) with polyester fiber utilized as stabilizer to satisfy the current necessities of clearing blends. A definitive folio content material (OBC) and prevalent fiber content material (OFC) have been inferred with the guide of utilizing Marshall Process. The OBC found as $4.5 \%$ for DBM-I. At that point considering OBC and OFC, the DBM-I blend were sorted out and restrictive appraisals like Marshall Properties and held steadiness test had been done to evaluate the results of polyester fiber as a stabilizer. It is finished up from present research that expansion of polyester fiber to blend upgrades the mix homes like Marshall Stability, Flow esteem and different living arrangements like explicit gravity, unit weight, etc. In DBM-I level of cover is $3.5 \%$ - $5 \%$ and percent of fiber is $0 \%-0.6 \%$ individually. All through the examinations it changed into discover there was improvement in indispensable properties like strength and stream Value, it transformed into discover that there was increment in dependability and diminishing in stream esteem therefore the expansion in security and lessen in stream esteem changed into $22 \%$ and $18 \%$ individually at $4.5 \%$ cover content.
\end{abstract}

Keywords - Dense bituminous macadam (DBM-I), polyester fibre, Marshall Properties, Retained stability.

\section{INTRODUCTION}

Bituminous spreads are extensively used by clearing industry. In vogue asphalts are characterized into organizations, i.e., bendy and firm asphalt. Bendy asphalt: adaptable asphalt might be portrayed as the one which incorporates a total of asphaltic or bituminous material and totals situated on a

\author{
Dr. Sandeep Singla \\ Department of Civil Engineering \\ RIMT University Mandi Gobindghar, Punjab, India
}

sleeping pad of compacted granular texture of appropriate charming in layers over the sub-grade. Water sure macadam streets and balanced out soil streets without or with asphaltic fixings are instances of bendy asphalts. Resolute asphalt in flexible asphalt is contained concrete or fortified solid chunks. Grouted solid streets are inside the classification of semi-firm asphalts. The design of unyielding asphalt is essentially founded on giving an auxiliary concrete solid chunk of adequate vitality to oppose the heaps from guests. The unbending asphalt has pressure and extreme modulus of versatility to disperse the heap over a phenomenally broad spot of soil. Minor varieties in sub-level vitality have little impact on the auxiliary capability of unbendable asphalt. Inside the structure of resolute asphalt, the flexural intensity of cement is the significant issue and no longer the vitality of sub-grade. In light of this property of asphalt, when the sublevel redirects underneath the unbending asphalt, the solid chunk is fit for connect over the restricted disappointments and districts of deficient help from sub-grade because of piece movement. Bituminous mix plan: the bituminous blend structure objectives to decide the portion of bitumen, filler, uncommon totals, and coarse totals to supply a blend that is reasonable, solid, tough and financially savvy. There are two assortments of the mix format, i.e., Dry mix format and wet blend plans.

General requirements of bituminous surface course: The top layer or surface course of flexible pavements of important roads has to withstand high stress conditions and wear and tear due to traffic loads. In addition, the surface course is exposed to adverse climatic factors including temperature variations, water, etc. Therefore properly designed high quality bituminous mixes are laid on the surface course of flexible pavements of important roads so as to sustain heavy traffic loads and wear and tear due to high speed vehicle movements. Apart from the high stability and durability, the bituminous surface has to provide good riding quality and surface texture to ensure non-slippery surface under wet weather.

Requirements of a pavement:

- An ideal pavement should meet the following requirements:

- Sufficient thickness to distribute the wheel load stresses to a safe value on the sub-grade soil,

- $\quad$ Structurally strong to withstand all types of stresses imposed upon it, 
- Adequate coefficient of friction to prevent skidding of vehicles,

- Smooth surface to provide comfort to road users even at high speed,

- Produce least noise from moving vehicles,

- Dust proof surface so that traffic safety is not impaired by reducing visibility,

- Impervious surface, so that sub-grade soil is well protected, and

- Long design life with low maintenance cost.

\section{Objectives of present research:}

The targets of this investigation are to take a look at the followings:

- To examine the Marshall properties of bituminous blend samples with distinct binder content material and its concentrations.

- To examine the Marshall properties of bituminous mix samples with various fibre attention using distinctive possibilities of binder.

- To research the consequences of Marshall Samples of bituminous blend for determining the most appropriate binder content (OBC) and gold standard fibre content material (OFC).

- To examine the retained stability check on Marshall Samples.

\section{MATERIALS AND TESTS:}

Constituents of bituminous mix and their characterization: the constituents of a dense graded bituminous mix to be used as surface course of a flexible pavement are:

- Course aggregates.

- Fine aggregates.

- Filler.

- Bituminous binder.

The gradation of the selected course aggregates should be such that the combined aggregates can fulfill the specified or desired gradation of the mixed aggregates. Selection of maximum size of course aggregates in the mix should be based on the compacted thickness the layer in which the mix is to be laid. Fine aggregates may be either manufactured or natural sand or a mix of both. The filler material consists of finely powdered mineral matter (85 to 100 percent passing $0.075 \mathrm{~mm}$ sieve) such as hydrated lime, Portland cement or rock dust or a mix of these, based on the requirements. Appropriate type and grade of bituminous binder is selected depending on climatic condition, with particular reference to the actual temperature range at the site. For instruction of dense grade bituminous mix (DBM-I ) aggregates as in step with MORTH grading as given in blow.
Table 1: Specified Grading for Dense Bituminous Macadam:

\begin{tabular}{|c|c|c|}
\hline Grading: & 1 & 2 \\
\hline $\begin{array}{l}\text { Nominal size of } \\
\text { Aggregate }\end{array}$ & $37.5 \mathrm{~mm}$ & $26.5 \mathrm{~mm}$ \\
\hline Layer thickness & $75-100$ & $50-75$ \\
\hline Is sieve size $(\mathrm{mm})$ & $\begin{array}{l}\text { Cumulative \% by } \\
\text { Weight of total } \\
\text { aggregate passing }\end{array}$ & \\
\hline 45.0 & - & 100 \\
\hline 37.5 & 100 & $95-100$ \\
\hline 26.5 & $90-100$ & $63-93$ \\
\hline 19.00 & $71-95$ & - \\
\hline 13.20 & $56-80$ & $55-75$ \\
\hline 9.5 & - & - \\
\hline 4.75 & $38-54$ & $38-54$ \\
\hline 2.36 & $28-42$ & $28-42$ \\
\hline 0.300 & $7-21$ & $7-21$ \\
\hline 0.150 & - & - \\
\hline 0.075 & $2-8$ & $2-8$ \\
\hline $\begin{array}{l}\text { Bitumen content } \\
\% \text { by mass of } \\
\text { total mix }\end{array}$ & 4 minimum & 4.5 minimum \\
\hline
\end{tabular}

Table 2: Observed gradation of aggregates for DBM-I mix:

\begin{tabular}{|c|c|c|c|c|c|c|}
\hline $\begin{array}{c}\text { Sieve } \\
\text { size }\end{array}$ & $\begin{array}{c}\text { Percen } \\
\text { tage } \\
\text { passin } \\
\mathrm{g} \\
40 \mathrm{~mm}\end{array}$ & $\begin{array}{c}\text { Percen } \\
\text { tage } \\
\text { passin } \\
\mathrm{g}\end{array}$ & $\begin{array}{c}\text { Percen } \\
\text { tage } \\
\text { passin } \\
\mathrm{g}\end{array}$ & $\begin{array}{c}\text { Percen } \\
\text { tage } \\
\text { passin } \\
\mathrm{g}\end{array}$ & $\begin{array}{c}\text { Percen } \\
\text { tage } \\
\text { passin } \\
\text { g Fine } \\
\text { Aggre } \\
\text { gate }\end{array}$ & $\begin{array}{c}\text { Percentage } \\
\text { passing stone } \\
\text { dust }\end{array}$ \\
\hline 37.5 & 100 & 100 & 100 & 100 & 100 & 100 \\
\hline 26.5 & 81 & 81 & 100 & 100 & 100 & 100 \\
\hline 19.00 & 14 & 14 & 60 & 100 & 100 & 100 \\
\hline 13.2 & 0.85 & 0.85 & 13 & 98 & 100 & 100 \\
\hline 4.75 & 0.06 & 0.06 & 0.16 & 36 & 98.8 & 99.2 \\
\hline 2.36 & 0.06 & 0.06 & 0.15 & 5.6 & 98.5 & 96.8 \\
\hline 0.300 & 0.03 & 0.03 & 0.12 & 1 & 32 & 17.7 \\
\hline
\end{tabular}




\begin{tabular}{|l|l|l|l|l|l|l|}
\hline 0.075 & 1 & 1 & 1 & 1 & 3 & 6 \\
\hline
\end{tabular}

Table 3: Percentage of Aggregate Size Taken for DBM-I mix:

\begin{tabular}{|c|c|c|c|c|c|}
\hline \multicolumn{6}{|c|}{ Calculated Blending for DBM grading no-1 } \\
\hline $40 \mathrm{~mm}$ & $20 \mathrm{~mm}$ & $10 \mathrm{~mm}$ & $\begin{array}{c}\text { Fine } \\
\text { Aggregate } \\
\text { Sand }\end{array}$ & $\begin{array}{c}\text { Stone } \\
\text { Dust }\end{array}$ & Total \\
\hline 10 & 30 & 20 & 15 & 15 & 100 \\
\hline
\end{tabular}

Table 4: Combined Gradation of the Sample Taken For DBM-I mix:

\begin{tabular}{|c|c|c|c|c|c|c|c|}
\hline $\begin{array}{l}\text { Requ } \\
\text { ired } \\
\text { sieve }\end{array}$ & $\begin{array}{c}\% \\
\text { Passi } \\
\text { ng } \\
\text { on } \\
40 \mathrm{~m} \\
\mathrm{~m}\end{array}$ & $\begin{array}{c}\% \\
\text { Passi } \\
\text { ng } \\
\text { on } \\
20 \mathrm{~m} \\
\mathrm{~m}\end{array}$ & $\begin{array}{c}\% \\
\text { Passi } \\
\text { ng } \\
\text { on } \\
10 \mathrm{~m} \\
\mathrm{~m}\end{array}$ & $\begin{array}{c}\% \\
\text { Passi } \\
\text { ng } \\
\text { on } \\
\text { sand }\end{array}$ & $\begin{array}{c}\% \\
\text { Passi } \\
\text { ng } \\
\text { on } \\
\text { stone } \\
\text { Dust }\end{array}$ & $\begin{array}{c}\text { Combine } \\
\mathrm{d} \\
\text { gradation }\end{array}$ & $\begin{array}{l}\text { Requir } \\
\text { ed } \\
\text { value }\end{array}$ \\
\hline 37.5 & 100 & 100 & 100 & 100 & 100 & $\begin{array}{l}9.98 \\
\end{array}$ & 100 \\
\hline 26.50 & 81 & 100 & 100 & 100 & 100 & 98.11 & 90 \\
\hline 19.00 & 14 & 60 & 100 & 100 & 100 & 83.28 & 71 \\
\hline 13.20 & 0.85 & 13 & 98 & 100 & 100 & 71.78 & 56 \\
\hline 4.75 & 0.06 & 0.16 & 36 & 98.8 & 99.2 & 44.17 & 38 \\
\hline 2.36 & 0.06 & 0.15 & 5.6 & 98.5 & 96.8 & 31.56 & 28 \\
\hline 0.300 & 0.03 & 0.12 & $\begin{array}{l}1.0 \\
\end{array}$ & 32 & $\begin{array}{l}17.7 \\
\end{array}$ & 7.87 & 7 \\
\hline 0.075 & 1 & 1 & 1 & 3 & 6 & 2.05 & 2 \\
\hline
\end{tabular}

Figure 1: Graphical representation Curve for DBM-I mix for Gradation.

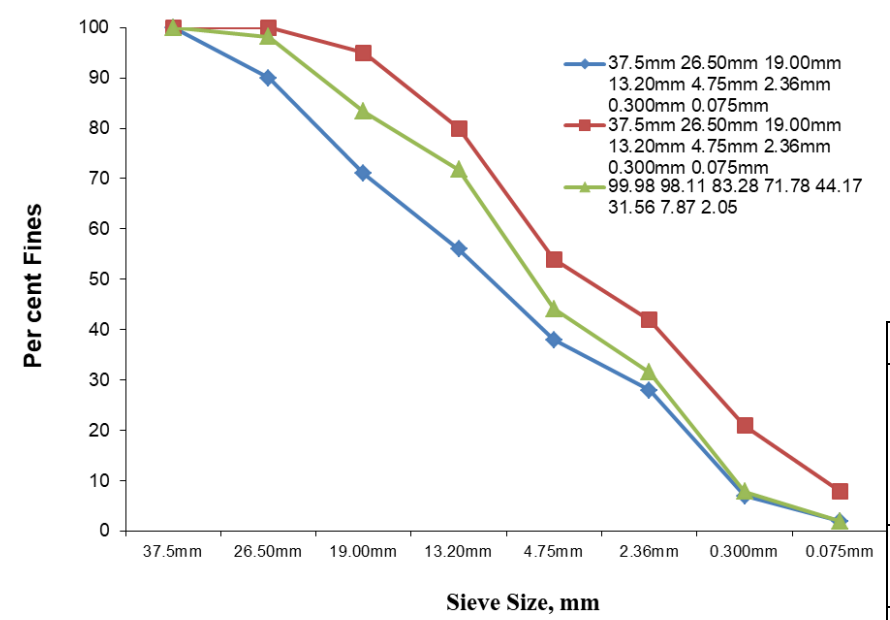

Tests on road aggregates: Tests which are generally carried out for judging the desirable properties and suitability of stone aggregates are listed below:

Table 5: Physical properties of coarse aggregates:

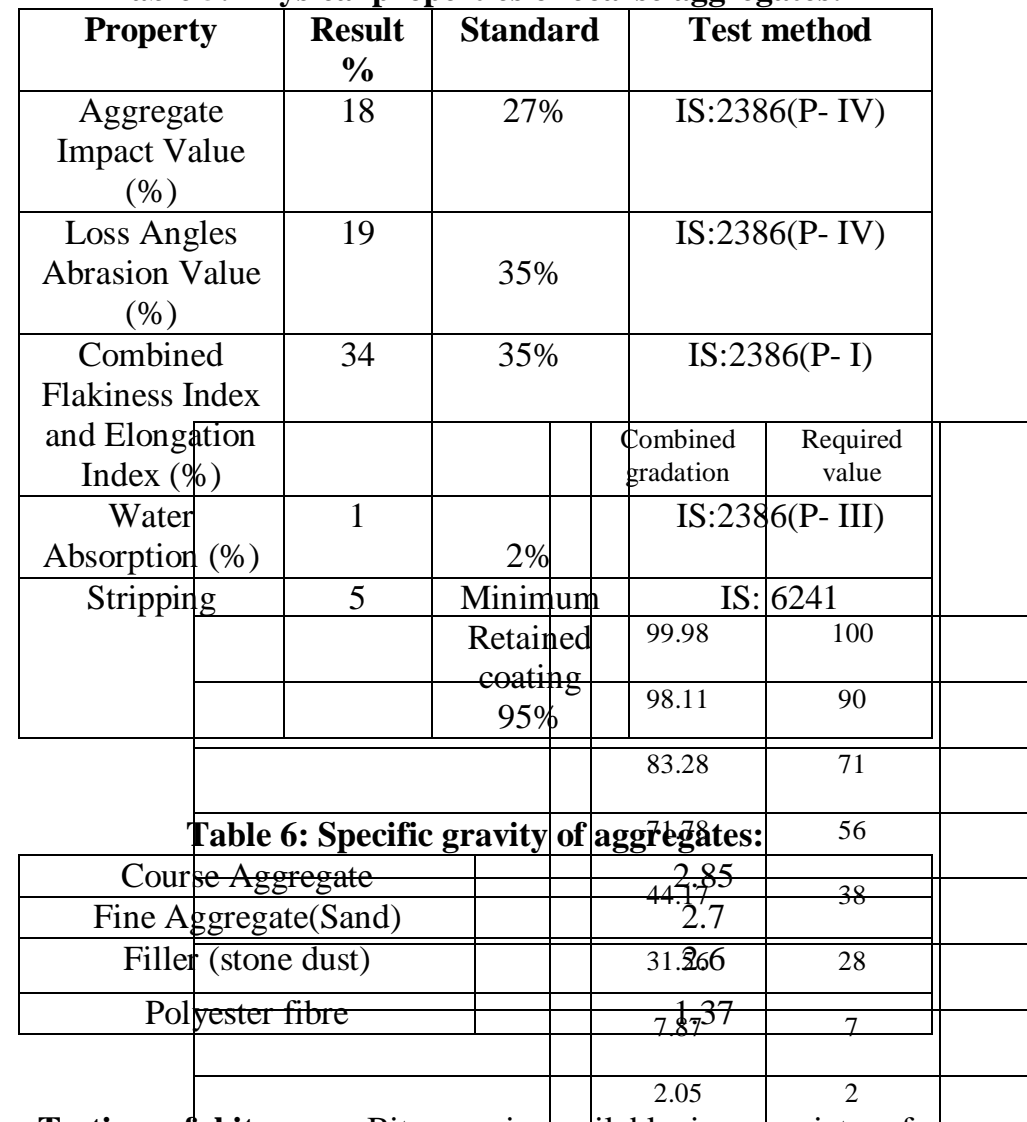

Testing of bittmen: Bitumen is avdilable in a variety of grades and types. To judge the suitability of these binders various physical tests have been specified by agencies like the bureau of Indian standards (BIS), American society for testing and materials (ASTM), Asphalt institute and the British standard institution. The common tests to assess the properties and requirements of paving grade bitumen are the viscosity tests, penetration test, ductility test and the softening point test. Also specific gravity test and flash and fire point tests are needed for use in paving applications. The take a look at outcomes of various bitumen checks are proven in table.

Table 7: Test results of Ingredient Bitumen Sample:

\begin{tabular}{|c|c|c|}
\hline Property & Result & Specification \\
\hline $\begin{array}{c}\text { Penetration at } \\
25^{\circ} \mathrm{C} / 100 \mathrm{gm} / 5 \\
\mathrm{sec},\end{array}$ & 82 & $80-100$ \\
$\mathrm{~mm}$ & & \\
\hline $\begin{array}{c}\text { Softening Point, } \\
{ }^{\circ} \mathrm{C}, \text { min. }\end{array}$ & 52 & $>40$ \\
\hline Ductility, cm & 100 & $>75$ \\
\hline Specific Gravity, & 1.02 & $0.97-1.02$ \\
\hline
\end{tabular}




\begin{tabular}{|c|c|c|}
\hline $\begin{array}{c}\text { at } \\
27^{\circ} \mathrm{C}\end{array}$ & \\
\hline $\begin{array}{c}\text { Absolute Viscosity } \\
\text { at } 60^{\circ} \mathrm{C}, \\
\text { Poise }\end{array}$ & 1052 & $800-1200$ \\
\hline $\begin{array}{c}\text { Kinematic } \\
\text { viscosity at } 135^{\circ} \mathrm{C}, \\
\text { C St. min. }\end{array}$ & 272 & $>250$ \\
\hline $\begin{array}{c}\text { Flesh and fire } \\
\text { point, min. }\end{array}$ & 220 and 240 & $>220$ \\
\hline $\begin{array}{c}\text { Test on residue } \\
\text { from rolling thin } \\
\text { flit oven test }\end{array}$ & & 350 \\
\hline $\begin{array}{c}\text { (a) Viscosity, } \\
\text { max. }\end{array}$ & 266 & $>75 \mathrm{~mm}$ \\
\hline $\begin{array}{c}\text { (b) Ductility at } \\
25^{\circ} \mathrm{C} \text { cm, min. }\end{array}$ & 100 & \\
\hline $\begin{array}{c}\text { Elastic Recovery, } \\
\mathrm{cm}\end{array}$ & 9 & \\
\hline
\end{tabular}

3.5 or $4 \%$ by weight of the mineral aggregates). The heated aggregates and bitumen are thoroughly mixed at a temperature of $154-160 \mathrm{oC}$. The mix is placed in a preheated mould and compacted by a rammer with 50 blows on either side at temperature of $138 \mathrm{oC}$ to $149 \mathrm{oC}$. The weight of mixed aggregates taken for the preparation of the specimen may be suitably altered to obtain a compacted thickness of $63.5+1-3$ $\mathrm{mm}$. Vary the bitumin content in the next trial by $+0.5 \%$ and repeat the above procedure. Number of trials aer predetermined. The prepared sample is loaded in the Marshall setup as shown in figure below.

Table 8: Properties of Polyester Fibre used:

\begin{tabular}{|c|c|}
\hline Test & Polyester Fibre \\
\hline Colour (visual) & White \\
\hline Shape & Circular \\
\hline Fibre width mm & 0.002 \\
\hline Fibre cut length $\mathrm{mm}$ & 6 \\
\hline Tensile strength- M pa & $9 \times 10^{\wedge} 4$ \\
\hline Modulus of Elasticity- $\mathrm{M}$ pa & $8 \times 10^{\wedge} 6$ \\
\hline Melting point- $\left({ }^{\circ} \mathrm{c}\right)$ & $>250$ \\
\hline Specific gravity-(g/cm^3) & 1.37 \\
\hline Moisture- (\%) & $<0.5$ \\
\hline Loss on ignition-(\%) & $<0.5$ \\
\hline Non fibrous material- (\%) & $<2.5$ \\
\hline
\end{tabular}

\section{Marshall Mix design:}

The Marshall Stability and flow test provides the performance prediction measure for the Marshall mix design method. The stability portion of the test measures the maximum load supported by the test specimen at a loading rate of 50.8 $\mathrm{mm} /$ minute. Load is applied to the specimen till failure, and the maximum load is designated as stability. During the loading, an attached dial gauge measures the specimen's plastic flow (deformation) due to the loading. The flow value is recorded in $0.25 \mathrm{~mm}$ (0.01 inch) increments at the same time when the maximum load is recorded. The important steps involved in marshal mix design are summarized next.

\section{Specimen preparation:}

Approximately $1200 \mathrm{gm}$ of aggregates and filler is heated to a temperature of $175-190 \mathrm{oC}$. Bitumen is heated to a temperature of $121-125 \mathrm{oC}$ with the first trial percentage of bitumen (say

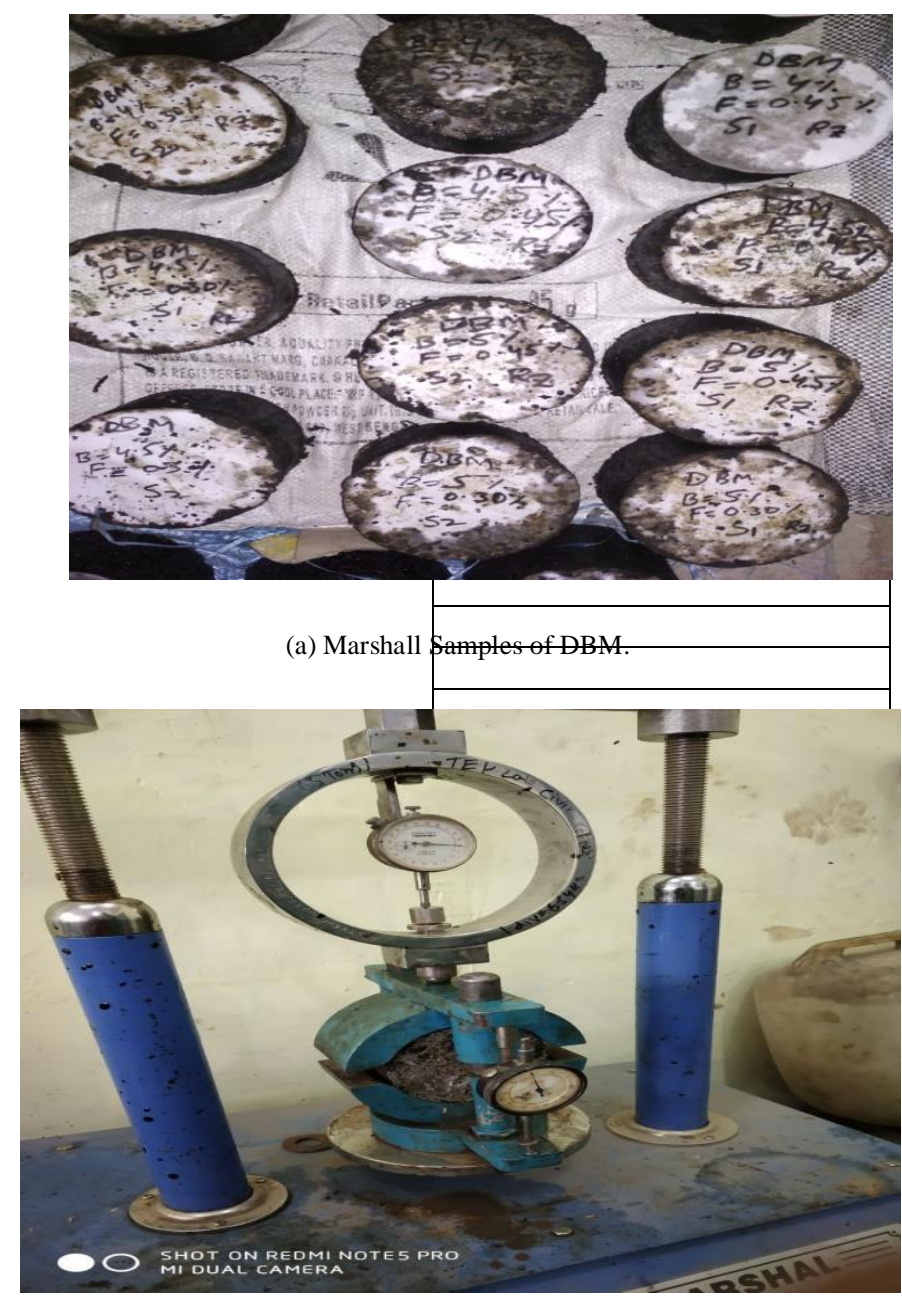

(c) Marshall Testing Machines.

1. Marshall Stability: it's far saw from diagrams that with blast in bitumen mindfulness the Marshall Steadiness worth will increment as much as positive bitumen content material and there after it diminishes. That exact bitumen content material is called as ideal folio content (OBC). In blessing study OBC for regular DBM-I blend are situated as $4.50 \%$ 
with polyester fiber at extraordinary consideration. From the diagrams it might be seen that with expansion of polyester fiber balance expense additionally will increment up as far as possible and further option diminishes the dauntlessness. This can be because of abundance measure of polyester fiber which can't blend in black-top appropriately. That polyester fiber focus in mix is called highest quality level polyester fiber content material (OFC) which is seen as $0.45 \%$ for DBM-I.

\begin{tabular}{|c|c|c|c|c|c|c|}
\hline $\begin{array}{c}\text { Fibre } \\
\text { content }\end{array}$ & $\mathbf{0 \%}$ & $\begin{array}{c}\mathbf{0 . 1 5} \\
\mathbf{\%}\end{array}$ & $\begin{array}{c}\mathbf{0 . 3 0} \\
\mathbf{\%}\end{array}$ & $\begin{array}{c}\mathbf{0 . 4 5} \\
\mathbf{\%}\end{array}$ & $\begin{array}{c}\mathbf{0 . 6 0} \\
\mathbf{\%}\end{array}$ & $\begin{array}{c}\text { Binder } \\
\text { content }\end{array}$ \\
\hline $\begin{array}{c}\text { Stability, } \\
\text { KN } \\
\text { DBM }\end{array}$ & 12.5 & 13.5 & 14.5 & 15.4 & 14.15 & $\mathbf{3 . 5 0 \%}$ \\
\hline & 13.6 & 15.3 & 16.4 & 17.4 & 15.88 & $\mathbf{4 \%}$ \\
\hline & 13.8 & 15.7 & 16.9 & 17.7 & 15.97 & $\mathbf{4 . 5 0 \%}$ \\
\hline & 10.3 & 12.4 & 13.3 & 14.6 & 12.87 & $\mathbf{5 \%}$ \\
\hline
\end{tabular}

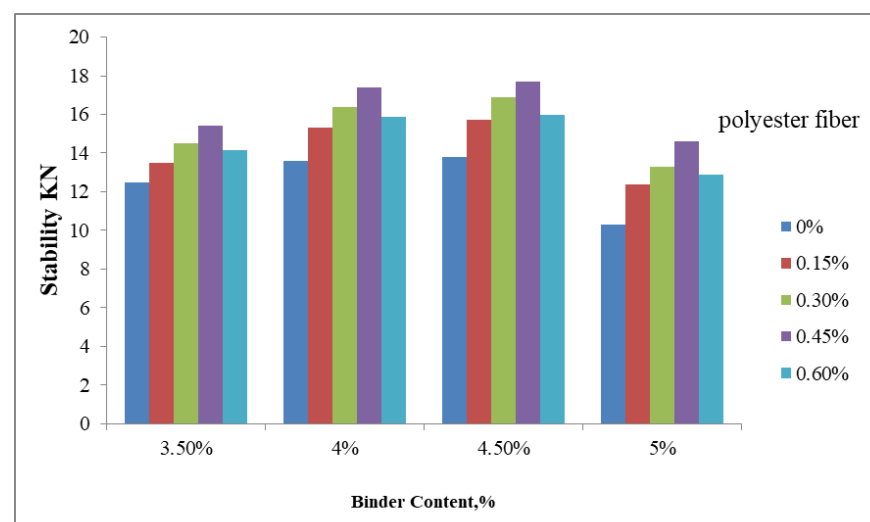

Figure 2: Binder content versus corrected Marshall Stability of DBM-I with Polyester fibre.

2. Flow value: It is seen from diagrams that with increment in fastener content stream esteem increments however by expansion of polyester Fiber stream esteem diminishes than that of regular blends, again further expansion of polyester Fiber after OFC the stream esteem begins to increment.

\begin{tabular}{|c|c|c|c|c|c|c|}
\hline $\begin{array}{c}\text { Fibre } \\
\text { content }\end{array}$ & $\mathbf{0 \%}$ & $\mathbf{0 . 1 5 \%}$ & $\mathbf{0 . 3 0 \%}$ & $\mathbf{0 . 4 5 \%}$ & $\mathbf{0 . 6 0 \%}$ & $\begin{array}{c}\text { Binder } \\
\text { content }\end{array}$ \\
\hline $\begin{array}{c}\text { Flow } \\
\text { Value } \\
\text { mm }\end{array}$ & 2.50 & 2.40 & 2.30 & 2.25 & 3.10 & $\mathbf{3 . 5 0 \%}$ \\
\hline & 2.70 & 2.60 & 2.34 & 2.18 & 3.15 & $\mathbf{4 . 0 0 \%}$ \\
\hline & 2.75 & 2.67 & 2.44 & 2.29 & 3.24 & $\mathbf{4 . 5 0 \%}$ \\
\hline
\end{tabular}

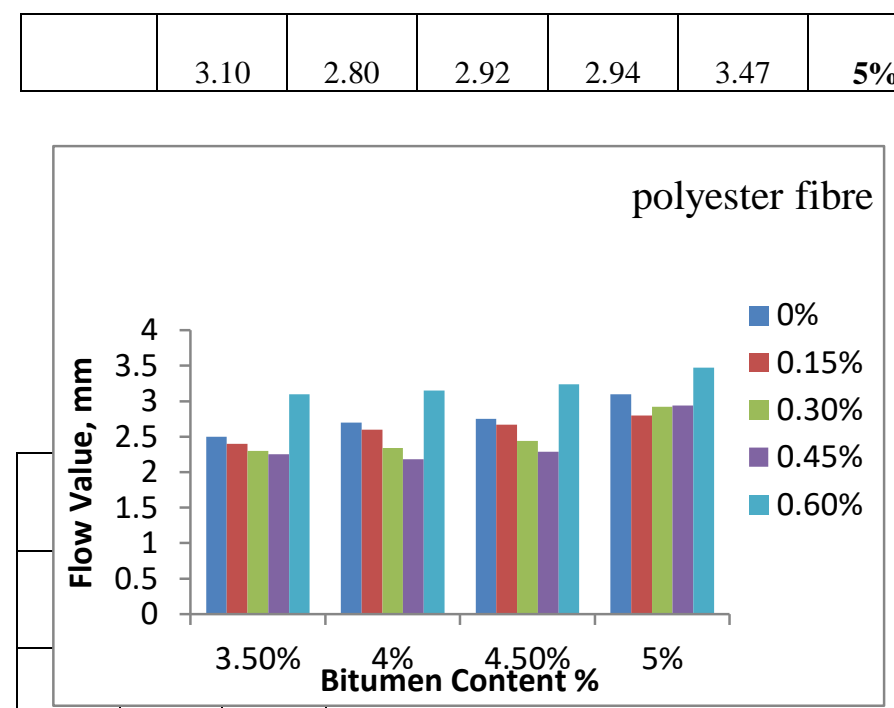

Figure 3: Binder content versus Marshall Flow of DMB-I with polyester fibre.

3. Unit Weight: It is seen that unit weight is expanding with increment in fastener focus up to certain cover content i.e., $\mathrm{OBC}$; at that point diminishing. With increment in polyester fiber fixation in blends its worth declines than ordinary blend. It happens might be because of lighter load of polyester fiber when contrasted with bitumen.

\begin{tabular}{|c|c|c|c|c|c|c|}
\hline $\begin{array}{c}\text { Fibre } \\
\text { content }\end{array}$ & $\mathbf{0 \%}$ & $\mathbf{0 . 1 5 \%}$ & $\mathbf{0 . 3 0 \%}$ & $\mathbf{0 . 4 5 \%}$ & $\mathbf{0 . 6 0 \%}$ & $\begin{array}{c}\text { Binder } \\
\text { content }\end{array}$ \\
\hline $\begin{array}{c}\text { unit } \\
\text { weight, } \\
\text { g/cc }\end{array}$ & 2.41 & 2.40 & 2.39 & 2.38 & 2.34 & $\mathbf{3 . 5 0 \%}$ \\
\hline & 2.43 & 2.41 & 2.40 & 2.39 & 2.35 & $\mathbf{4 \%}$ \\
\hline & 2.44 & 2.42 & 2.41 & 2.40 & 2.36 & $\mathbf{4 . 5 0 \%}$ \\
\hline & 2.41 & 2.39 & 2.37 & 2.36 & 2.33 & $\mathbf{5 \%}$ \\
\hline
\end{tabular}

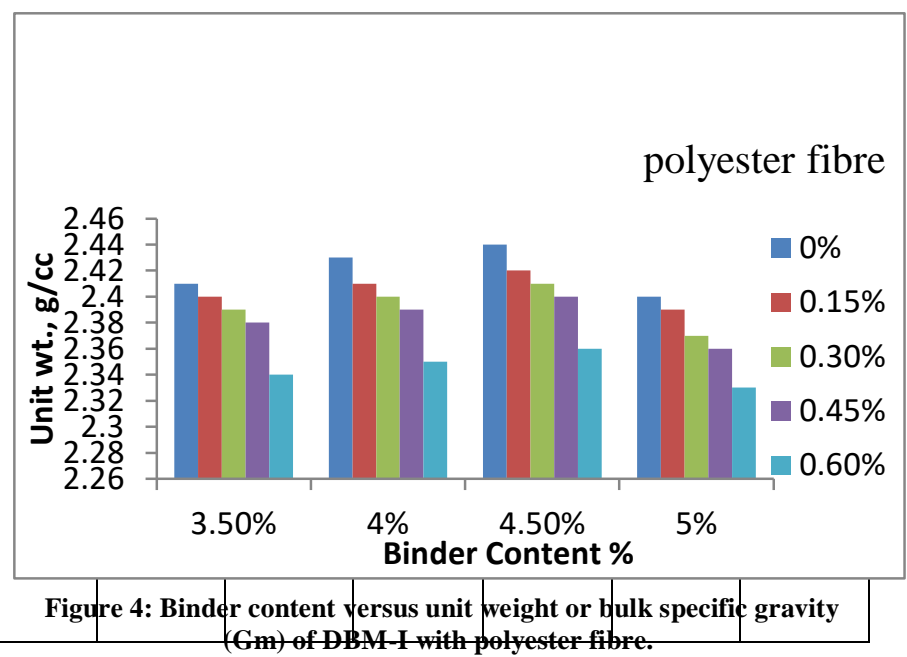


4. Air Void (VA): It is seen that with increment in cover content air void declines. Yet, with expansion of polyester fiber to blend the air void is expanding than that of traditional blends.

\begin{tabular}{|c|c|c|c|c|c|c|}
\hline $\begin{array}{c}\text { Fibre } \\
\text { Value }\end{array}$ & $\mathbf{0 \%}$ & $\mathbf{0 . 1 5 \%}$ & $\mathbf{0 . 3 0 \%}$ & $\mathbf{0 . 4 5 \%}$ & $\mathbf{0 . 6 0 \%}$ & $\begin{array}{c}\text { Binder } \\
\text { Content }\end{array}$ \\
\hline $\begin{array}{c}\text { \% Air } \\
\text { Voids }\end{array}$ & 3.0 & 3.15 & 3.28 & 3.35 & 4.20 & $\mathbf{3 . 5 0 \%}$ \\
\hline & 3.15 & 3.25 & 3.38 & 3.60 & 4.38 & $\mathbf{4 \%}$ \\
\hline & 3.30 & 3.45 & 3.54 & 3.76 & 4.82 & $\mathbf{4 . 5 0 \%}$ \\
\hline & 3.45 & 3.60 & 3.73 & 4.10 & 4.76 & $\mathbf{5 \%}$ \\
\hline
\end{tabular}

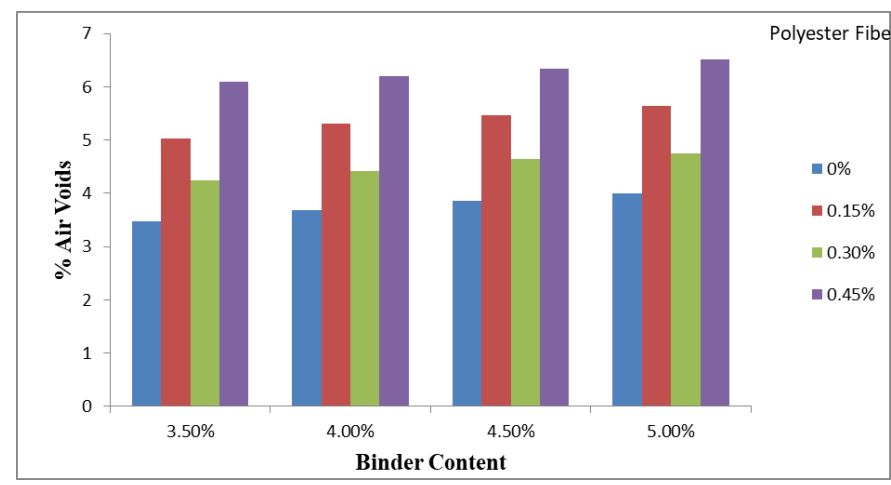

Figure 5: Binder content versus percentage of void $(\mathrm{Vv})$ in the total mix of DBM-I with polyester fibre.

5. Void in mineral aggregate (VMA): It is seen that first VMA diminishes and afterward it increments at sharp rate with increment in bitumen focus in blends. Variety of VMA values with various fastener substance and with various polyester fiber substance are appeared in charts underneath. From the diagrams it is seen that with expansion of polyester fiber to blend the VMA esteems increments than that of ordinary blends.

\begin{tabular}{|c|c|c|c|c|c|c|}
\hline $\begin{array}{c}\text { Fibre } \\
\text { Content }\end{array}$ & $\mathbf{0 \%}$ & $\mathbf{0 . 1 5 \%}$ & $\mathbf{0 . 3 0 \%}$ & $\mathbf{0 . 4 5 \%}$ & $\mathbf{0 . 6 0 \%}$ & $\begin{array}{c}\text { Binder } \\
\text { Content }\end{array}$ \\
\hline $\begin{array}{c}\text { \% } \\
\text { VMA }\end{array}$ & 13.23 & 14.56 & 15.96 & 16.42 & 17.11 & $\mathbf{3 . 5 0 \%}$ \\
\hline & 14.22 & 15.34 & 16.34 & 17.11 & 18.23 & $\mathbf{4 \%}$ \\
\hline & 15.11 & 16.42 & 17.63 & 18.21 & 19.54 & $\mathbf{4 . 5 0 \%}$ \\
\hline & 16.23 & 17.42 & 18.11 & 19.52 & 20.45 & $\mathbf{5 \%}$ \\
\hline
\end{tabular}

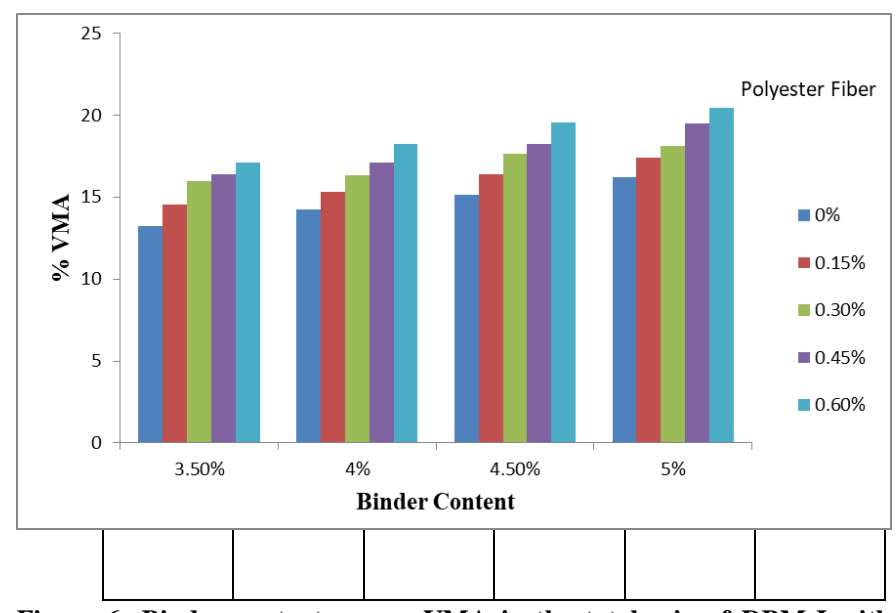

Figure 6: Binder content versus VMA in the total mix of DBM-I with polyester fibre.

6. Void filled with bitumen (VFB): It is seen that VFB estimations of various blends increment at sharp rate in with increment in bitumen fixation. Variety of VFB with various folio content with various polyester fiber content is appeared in charts beneath. From these charts it is seen that with expansion of polyester fiber to blend the VFB increments than that of customary blends.

\begin{tabular}{|c|c|c|c|c|c|c|}
\hline $\begin{array}{c}\text { Fibre } \\
\text { Conte } \\
\text { nt }\end{array}$ & $\mathbf{0 \%}$ & $\mathbf{0 . 1 5 \%}$ & $\begin{array}{c}\mathbf{0 . 3 0} \\
\mathbf{\%}\end{array}$ & $\begin{array}{c}\mathbf{0 . 4 5} \\
\mathbf{\%}\end{array}$ & $\begin{array}{c}\mathbf{0 . 6 0} \\
\mathbf{\%}\end{array}$ & $\begin{array}{c}\text { Binder } \\
\text { Content }\end{array}$ \\
\hline $\begin{array}{c}\text { \% } \\
\text { VFB }\end{array}$ & 60.12 & 62.34 & 64.25 & 66.57 & 68.22 & $\mathbf{3 . 5 0 \%}$ \\
\hline & 62.45 & 64.75 & 66.71 & 68.74 & 70.42 & $\mathbf{4 \%}$ \\
\hline & 64.54 & 66.72 & 68.64 & 70.86 & 72.32 & $\mathbf{4 . 5 0 \%}$ \\
\hline & 66.15 & 68.95 & 70.32 & 72.56 & 74.55 & $\mathbf{5 \%}$ \\
\hline
\end{tabular}

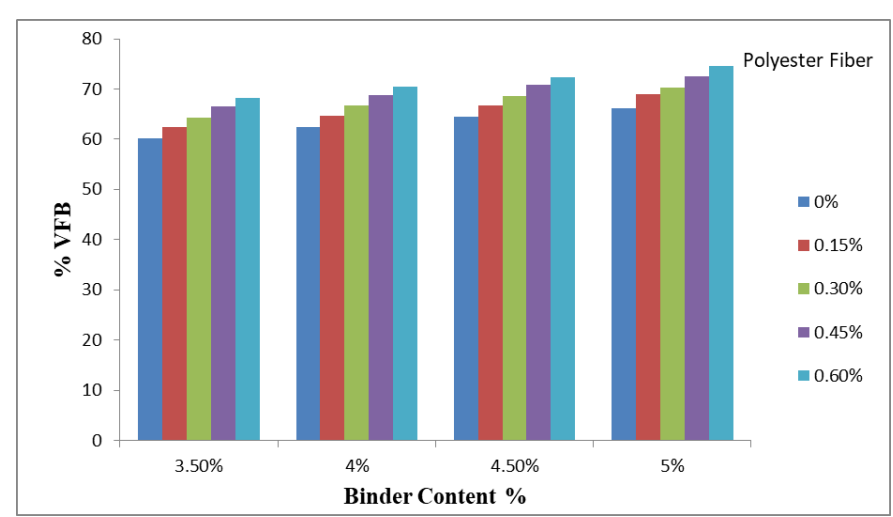

Figure 7: Binder content versus voids filled with bitumen (VFB) of DBMI with polyester fibre. 


\section{RESULTS AND DISCUSSIONS:}

Determine optimum bitumen content:

Determine the optimum binder content for the mix design by taking average value of the following three bitumen contents found form the graphs obtained in the previous step.

1. Binder content corresponding to maximum stability

2. Binder content corresponding to maximum bulk specific gravity $(\mathrm{Gm})$

3. Binder content corresponding to the median of designed limits of percent air voids $(\mathrm{Vv})$ in the total mix (i.e. $4 \%$ )

The stability value, flow value, and V FB are checked with Marshall Mix design specification chart given in Table below. Mixes with very high stability value and low flow value are not desirable as the pavements constructed with such mixes are likely to develop cracks due to heavy moving loads.

Table 9: Mix design Requirements for DBM:

\begin{tabular}{|c|c|}
\hline Test property & Specified value \\
\hline $\begin{array}{c}\text { Marshall stability (Kg at } \\
\left.60^{\circ} \mathrm{C}\right)\end{array}$ & 900 minimum \\
\hline Flow Value (mm) & $2-4$ \\
\hline $\begin{array}{c}\text { Compaction level (no. Of } \\
\text { blows) }\end{array}$ & 50 blows for DBM \\
\hline $\begin{array}{c}\text { Percent Air Voids, } \% \\
\text { VFB, } \%\end{array}$ & $3-5$ \\
\hline
\end{tabular}

Table 10: Optimum binder contents:

\begin{tabular}{|c|c|c|}
\hline Types of mix & $\begin{array}{c}\text { Optimum } \\
\text { polyester fibre } \\
\text { Content }(\%)\end{array}$ & $\begin{array}{c}\text { Optimum binder } \\
\text { content } \\
(\%)\end{array}$ \\
\hline $\begin{array}{c}\text { DBM-I without } \\
\text { polyester fibre }\end{array}$ & $0 \%$ & $4.5 \%$ \\
\hline $\begin{array}{c}\text { DBM-I with } \\
\text { polyester fibre }\end{array}$ & $0.45 \%$ & $4.5 \%$ \\
\hline
\end{tabular}

Table 11: comparisons of stabilities at $\mathrm{OBC}$ :

\begin{tabular}{|c|c|}
\hline Types of mix with stone dust & Stability(KN) \\
\hline DBM-I without polyester fibre & 13.80 \\
\hline DBM-I with polyester fibre & 17.70 \\
\hline
\end{tabular}

Table 12: Comparisons of flow values at OBC:

\begin{tabular}{|c|c|}
\hline Types of mix with stone dust & Flow Value (mm) \\
\hline DBM-I without polyester fibre & 2.75 \\
\hline DBM-I with polyester fibre & 2.29 \\
\hline
\end{tabular}

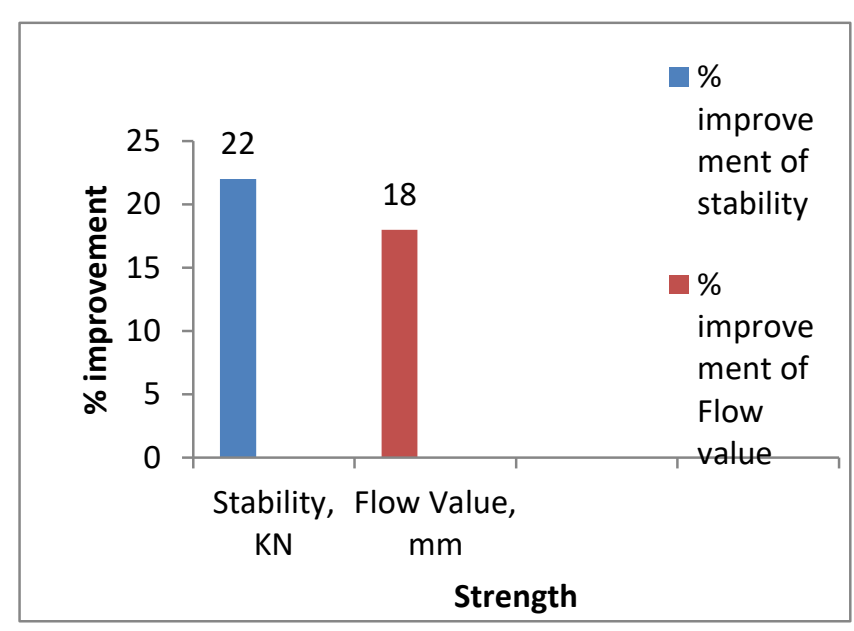

Figure 8: Calculation of \% improvement in properties of \begin{tabular}{ll} 
DBM-I. \\
\cline { 3 - 3 } The improved properties like & stability has increased and Flow
\end{tabular} value has decreased during the research work for DBM-I at $4.5 \%$ binder content by values of $22 \%$ and $18 \%$ respectively.

Table 13: Calculation of improved results.

\begin{tabular}{|c|c|c|c|}
\hline \multirow[t]{3}{*}{ Types of mix } & \multirow{3}{*}{$\begin{array}{c}\text { DBM } \\
\text { without } \\
\text { polyester } \\
\text { fibre }\end{array}$} & \multirow{2}{*}{$\begin{array}{c}\text { DBM with } \\
\begin{array}{c}\text { polyester } \\
\text { fibre }\end{array} \\
\end{array}$} & Improved \\
\hline & & & Result, \% \\
\hline & & & \\
\hline Stability(KN) & 13.80 & 17.70 & 22 \\
\hline Flow & 2.92 & 3.40 & 18 \\
\hline value (mm) & & & \\
\hline \multicolumn{4}{|c|}{$\begin{array}{l}\text { Retained stability: Held Steadiness is the proportion of } \\
\text { dampness actuated striping in the blend and ensting loss } \\
\text { security because of debilitated bond among totals and folio } \\
\text { The test was directed after MORTH- } 2013 \text { on the Marshal } \\
\text { machine with the typical Marshall tests. The solidness was } \\
\text { resolved in the wake of setting the examples in water shower a } \\
60^{\circ} \mathrm{C} \text { for } 30 \text { minutes and } 24 \text { hours. Held strength is determined } \\
\text { for DBM-I blend in with and without polyester fiber. It is seen } \\
\text { that the expansion of polyester fiber to the blend then the held } \\
\text { soundness esteem increments. It is broke down that with } \\
\text { polyester fiber brings about most noteworthy herc } \\
\text { dependability pursued by DBNA-I without polyester fiber. }\end{array}$} \\
\hline
\end{tabular}

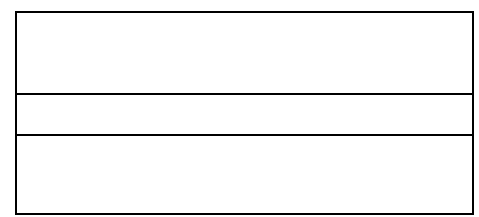


Table 14: Held soundness of DBM-I with and without polyester fiber:

\begin{tabular}{|c|c|c|c|c|}
\hline $\begin{array}{c}\text { Types of } \\
\text { mix }\end{array}$ & $\begin{array}{c}\text { Avg. } \\
\text { solidness } \\
\text { after } \\
\text { half an } \\
\text { hour in } \\
\text { water } \\
\text { at } \mathbf{6 0}^{\circ} \text { c }\end{array}$ & $\begin{array}{c}\text { Avg. } \\
\text { solidness } \\
\text { after 24 } \\
\text { hours } \\
\text { ins } \\
\text { water at } \\
\mathbf{6 0}^{\circ} \mathbf{c}\end{array}$ & $\begin{array}{c}\text { Avg. } \\
\text { retained } \\
\text { solidness, } \\
\text { in \% }\end{array}$ & $\begin{array}{c}\text { Design } \\
\text { requirement }\end{array}$ \\
\hline $\begin{array}{c}\text { DBM-I } \\
\text { without } \\
\text { polyester } \\
\text { fibre }\end{array}$ & 12.55 & 11.25 & 89.64 & $\begin{array}{c}\text { Minimum } \\
75 \% \\
\text { (as per } \\
\text { MORTH }\end{array}$ \\
\hline $\begin{array}{c}\text { DBM-I } \\
\text { with } \\
\text { polyester } \\
\text { fibre }\end{array}$ & 17.70 & 14.65 & 82.76 & $\begin{array}{c}\text { Minimum } \\
\text { Table 500-17) } \\
\text { (as per } \\
\text { MORTH } \\
\text { Table 500-17). }\end{array}$ \\
\hline
\end{tabular}

4. Das A and Chakroborty P (2010), "Principles of Transportation Engineering", pp. 294-299, Prentice Hall of

India, New Delhi.
5. Das A, Deol M S, Ohri S and Pandey B B (2004),

"Evolution of Non-Standard Bituminous Mix-A Study on Indian Specification", The International Journal of Pavement Engineering, Vol. 5, No. 1, pp. 39-46.

6. IS: 2386 (1963), "Methods of Test for Aggregates for Ooncrete (P - I): Particle Size and Shape", Bureau of Indian Standards, New Delhi.

7. IS: 1203 (1978), "Methods for Testing Tar and Bituminous Materials: Determination of Penetration", Bureau of Indian Standards, New Delhi.

8. Jony Hassan H and Jahad Israa Y (2010), "The Effect of Using Glass Power Filler on Hot Asphalt Concrete Mixture Ptoperties", Engg and Technology Journal, Vol. 29, No. 1, pp. 44-57.

9. Karasahin Mustafa and Terzi Serdal (2007), "Evaluation of Marbal Waste Dust in Mixture of", Construction and Building Materials, Vol. 21, No. 5, pp. 616-620.

10. Kamraj C, Kumar G, Sharma G, Jain P K and Venkanna Babu P (2004), "Laboratory Studies on the Behaviour of Stone Matrix Asphalt vis-à-vis Dense Graded Bituminous Mixes Using Natural Rubber Powder (Wet Process)", Highway Research Bulletin, No 71, IRC, pp. 39-60, New Delhi.

In this investigation, the DBM-I are sorted out with VG10 grade bitumen utilized as a folio. The effect of expansion of polyester fiber inside the bituminous blends has been examined with the guide of changing centralizations of polyester fiber from $0 \%$ to $0.6 \%$ at an augmentation of $0.15 \%$. 1. During Studies discoveries we locate the essential properties like parity quickened and the stream esteem diminished by method for $22 \%$ and $18 \%$ individually at $4.5 \%$ best bitumen content $(\mathrm{OBC})$ and $0.45 \%$ top-quality polyester fiber content material (OFC) for DBM-I

2. During Studies discoveries the held equalization of the blend plan DBM-I increments with polyester fiber. From the above perceptions it's far reasoned that utilization of polyester fiber results in ventured forward building homes of bituminous blends.

\section{REFERENCE}

1. Brown E R and Manglorkar H (1993), "Evaluation of Laboratory Properties of SMA Mixtures", NCAT Report No. 93-5, Auburn University, Alabama.

2. Brown E R and Mallick R B (1994), "Stone Matrix Asphalt Properties Related to Mixture Design”, NCAT Report 94-02.

3. Bradley J Putman and Serji N Amirkhanian (2004), "Utilization of Waste Fiber in Stone Matrix Asphalt Mixtures", Resources, Conservation and Recycling, Vol. 42, No. 3, pp. 265-274. 11. Khanna S K and Justo C E G (2001), "Highway Engineering", pp. 315-321, Nem Chand and Bros, Roorkee.

12. Yongjie Xue, Haobo Hou, Shujing Zhu and Jin Zha (2009), "Utilization of Municipal Solid Waste Incineration Ash in Stone Mastic Asphalt Mixture: Pavement Performance and Environmental Impact", Construction and Building Materials, Vol. 23, No. 2, pp. 989-996.

13. Li, WL, Han, LN and Guan, NF, (2004). Influence of polyester fibre on asphalt mixes. Liaoning Communication Science and Technology, 2 pp $4-16$ (in Chinese).

14. Li, WG, Zhang, ZQ, Zhang DL, Zhang, J and Luan, F, (1998). Research on fibre reinforcement of asphalt pavements. Journal of Xi'an Highway University, 7 pp 235 - 238 (in Chinese).

15. Peng, B, Li, WY and Dai, JL, (2003). Application of fibre in asphalt concrete. Highway Engineering of Central-South China, 6 pp $44-46$ (in Chinese).

16. Wu, SP, Xue, YJ and Zhang, DF, 2003. Research on asphalt concrete with polyester fibres. Journal of the Wuhan University of Science and Engineering, 12 pp 47 - 49 (in Chinese). 